\author{
G.A. Rizakhojayeva, N.S. Ibadullayeva \\ Khoja Akhmet Yassawi International Kazakh-Turkish University, Turkistan \\ (E-mail: gulnara_rizahodja@mail.ru)
}

\title{
Educational Action Research as a Powerful Vehicle for Transformation
}

\begin{abstract}
Thanks God for living and learning throughout my life.
One of the most significant challenges in the educational field is teachers' inability to combine teaching and research in the context of action research process as a theory-driven and practice-based approach. To address this issue, the article considers detailed theoretical and practical action research background, challenges revealed in six countries and problems in Kazakhstan education in the light of critical reflection: comparison and contrast, similarities and differences. Similar issues revealed when studying different countries' action research approaches are as follows: teachers' personal, intrapersonal, social, professional and cultural challenges, insufficient knowledge about action research theory and practice, problems with documenting findings and representing results. To solve these complicated issues the author suggests principles of sequential action research procedure, introducing action research courses into in-service teachers' retraining qualification courses as one of the primary requirements to conduct school research systematically, including 'a theory and practice based research' discipline into universities in order to encourage undergraduates and postgraduates to design 'action research handbook'. Overall, action research approach will be an ultimate tool for reconstructing curriculum aims and principles, remodeling teaching strategies and techniques in case numerous barriers are resolved jointly under teachers' constructive and collaborative critical reflection.
\end{abstract}

Keywords: action research, teacher researchers, challenges, theory and practice, teaching practice, curriculum, process.

It is rather difficult for teachers to address and resolve teaching and learning-based problems in the classroom environment when conducting action research (AR) process. Therefore, teachers' inability to combine theory and practice in their AR process has yet to be explored. Addressing this problem will undoubtedly have benefits for teachers' future progress. The purpose of the study is to explore AR theory and practice in in-service teacher education and highlight its importance in resolving teaching and learning issues, curriculum reconstruction and academic staff development.

\section{Literature Review: Action Research Theoretical and Practical Background}

Continuous professional development (CPD) in teacher education requires from teachers a combination of action and research or action research (AR) as a powerful vehicle for transformation. To what extent AR process is efficient in the contexts of problem solving, curriculum reconstruction and effective continuous professional development approach from a theoretical point of view? Clearly, from the perspective of many academics, theoreticians and researchers [1,2], action research approach proves its effectiveness as a problem solving approach related to ongoing empirical investigation, conducted by individual teachers, team members and academic staff to diagnose and resolve learning based problems in order to improve teaching styles, strategies and techniques, develop school curriculum aims and principles in individual, school and district form with the purpose of transforming and improving teachers' professional development in the light of critical reflection. From the perspective of Kemmis, AR is a longitudinal paradigm shift that incorporates saying (understanding and thinking), doing (actions) and relating (conditions, circumstances, educational setting, and relationships with others) practices [3] which subsequently as a result of continuous AR conduction become entirely coherent and interactive. Investigating Stenhouse's 'process model' deeply, Elliott contends that educational action research as a means of 'ethical enquiry' shapes up self-directed learning by which educational aims, designed by teacher researchers, are reconstructed into central curriculum aims and principles of learner centered education. Stenhouse [4] claims that maximum productivity of cooperative team teachers' action research is worthy of consideration as one unanimous collaborative community with its theory comprehension, rigorous analytical research, aspiration for self-criticism and confidence to present its project to general judgment rather than individual teacher's research which lacks sharing ideas and team discussion. In addition to Stenhouse's viewpoint, Eliott argues that AR achieves its higher level in case it is assisted and instructed by experts and academics to guide them during the process. According to Kemmis, AR 
progress is basically dependent on team teachers' real critical reflection on the basis of 'confusion, contradiction and conflict'. On the one hand, objective critical assessment is an ultimate tool for teacher researchers to find strengths and weaknesses and give constructive feedback which makes their research analytical, valid and reliable, on the other hand, it may cause emotional stress and misunderstandings on the part of both students and teachers undergoing through the experiment. Elliot considers AR as 'a form of ethical inquiry' with the help of which, students' and teachers' creativity, individuality and freedom to discuss openly is welcomed as it is viewed clearly as 'virtue ethics' in Aristotle's practical wisdom [5]. On the contrary to Elliott's viewpoint about AR ethical values within the context of 'behavioral objective model' Carr argues [6] that ethical knowledge is not always consistent with the idea of consensus, general agreement and solidarity because raised controversial issues can be ultimately resolved when there are 'democratic virtues' in the context of hot discussion, contradiction and disagreement with some controversy research aspects which in its turn lead to constructive decision made by research community.

Does the effectiveness of AR approach, proved theoretically by academics, demonstrate the truth in practice? How do teachers combine AR theory and methodology together in their school practice? What challenges do teacher researchers face when conducting action research in the classroom environment?

As AR is a powerful vehicle for enhancing both teaching and learning outcomes, it requires from teachers to become researchers which is a challenging task for them to realize. At the present time teacher researchers confront with a wide range of AR issues in teaching practice which constitute teachers' theoretical and methodological lack of research knowledge, as it was argued by Stenhouse, challenges in individual, internal, external, personal, interpersonal, professional and cultural contexts. For example, Pearson [7] in her writing assessment process folio AR project, conducted throughout 2013-2015 at the UK institution, points out that AR practice is quite a risky under-used process with ethical, theoretical and practical issues which may cause emotional stress, tension among students and teacher practitioners who are constrained by social structures, free time, motivation and in-depth engagement with AR theory and literature review. However, she outlines the necessity of AR practice as the $21^{\text {st }}$ century vehicle for transformation that emerges from 'imminent critique'. Comparatively, challenges found out by Elliott when examining educational AR accounts, published in the Educational Action Research Journal throughout 2013-2014 as follows: first, in most articles there is focus and reflection on actions rather than on transformation of actions into aims as 'fixed ends'. Second, not all teacher researchers can formulate Stenhouse's 'principles of procedure' concretely to move forward and overcome teaching and learning barriers during the research process. Third, most articles involve research findings and results which are not generalized clearly following the critical assessment criteria of comparison and contrast, similarity and difference from different practical situations. Fourth, authors represent findings basically focused on teacher researchers' strengths and weaknesses rather than students' learning barriers and progress. Together with this, teachers consider AR project the next burden overloaded with documents, stressed by administration pressure and required to be responsible for their teaching practice.

Ellis and Loughland [8] carried out a comparative case study with 42 Singapore and NSW teacher practitioners from government and independent schools who were interviewed with the aim of comparing whether these two countries' teacher practitioners' challenges are similar or different and how these challenges could serve a basis for remodeling their research projects in order to change their school teaching practice. First, problems, revealed in both countries, constituted both theoretical and methodological aspects of research. One of the reasons for their shortage of knowledge according to their responses was inadequate research theory introduced to them when they were undergraduates. Second, documenting research findings, required from Singapore teachers, turned out to be quite problematic for them because they did not encounter such a procedure before. Third, qualitative analysis was the next barrier for Singapore teachers to represent their findings and results properly due to insufficient training sessions during the research practice. Identically, NSW teachers needed school leaders to direct and support them how to write academic articles after finishing their research projects. Similar challenges were associated with time and syllabus pressure on teachers with limited opportunities for critical reflection. To overcome these barriers the authors suggest inviting experts and trainers to schools and setting up an open educational research platform between academic advisers and teachers as learners for their further continuous collaborative interaction.

Thailand school teachers' 4 month quasi-experimental research [9] involved 83 subjects from 9 Bangkok schools with the purpose of improving school learning and developing teachers' 5 disciplines which were elaborated by Senge: a person's ability to learn continuously, mental model, shared vision, team learning, systems thinking. Researchers revealed numerous issues in identifying classroom action research (CAR) 
objectives, developing research tools, critical reflection of CAR process, evaluating learning outcomes, constructing life-long learner components (competency, desire to learn and reflective thinking), time and budget limitation, insufficient CAR knowledge and teaching skills, school teachers' obedience to school policies, overloaded content to teach, less motivation to conduct CAR continuously and less confidence to test innovative methods and approaches. Despite the various issues, revealed transparently in terms of reasonable critical reflection and proper research ethics, the project also had benefits such as teachers' desire to improve their teaching practice and work together in collaboration, learning from experience, knowledge sharing, developing inquiry skills, curriculum structure improvement, and teachers' higher mental model. More importantly, conducting AR training sessions in parallel with CAR process enabled Bangkok teachers to gain a deeper understanding about how to incorporate educational theory into practice. In contrast, Dehghan, and Sahragard's study of 89 Iranian elementary and secondary school teachers' questionnaire and interview results [10] according to their beliefs about CAR process indicates that teachers consider this type of research quite useless to conduct continuously despite their familiarity with the theory of action research from their in-service courses and workshops. In spite of the fact that teachers have a considerable number of problems such as students' low motivation and difficulties in second language acquisition (SLA), their low language proficiency level, students' discipline problems, overloaded classrooms, they do not regard CAR as a beneficial approach to solve faced issues. In other words, they are fixed to the ideology of 'research must be performed by professional experts not by teachers. Interestingly, in Iranian study most teachers prefer to do research individually rather than in a collaborative form. In addition, they are not likely to consult other researchers, experts, and share their findings with their colleagues which undoubtedly, block their way of addressing CAR process as an efficient problem solving approach. Conversely to Iranian teachers, interviewed 11 Philippine teachers from 11 different public high schools [11] welcomed AR stating that the research project contributed to their growing both personally and professionally, thus they got positive effect on teaching and learning process. Nevertheless, there were some challenges such as insufficient school support, research skills, lack of resources in the library, problems with internet access, and misbalance between work life and personal life. Some Philippine teachers' motivation was based on the fact that they tend to do research with the purpose of improving financial status, receiving a $\mathrm{MA}$ and $\mathrm{PhD}$ degree, job promotion and salary increase rather than helping students to overcome learning barriers together.

What needs to be done to overcome AR challenges in teacher education? To address the problematic question, the article provides information about how to combine AR theory and methodology coherently, how to resolve AR issues revealed in different countries' enquiry, which in its turn may shed the light on effective professional development.

\section{Theory and Practice: How to Conduct Action Research in Teaching Practice}

Historical development of AR as spiral steps of circles of planning, action and fact finding goes back to social psychologist K. Lewin, 'father of action research' who devised a social AR focused on industry, military, political and economic systems enquiry. There are different models of AR cycles elaborated by researchers. Kemmis and McTaggart's action research of retrieved spiral cycle of planning, action, observing and reflecting is worthy of consideration [12]. Further, McKernan's AR time process model, based on curriculum planning, consists of such sequential stages as problem situation, defining problem, needs assessment, hypothesis ideas, developing action plan, implementing plan, evaluating action, and decisions (reflecting, explaining, understanding action) which are explored by democratic, critical thinking research community of teachers. The main characteristic feature of this cyclical model is that research problem, identified and analyzed in the first cycle, can be redefined in the second cycle with the purpose of curriculum improvement [13]. Next, AR cycle elaborated by A. Burns represents 11 interrelated sequential movements of exploring, identifying, planning, collecting data, analyzing/reflecting, hypothesizing/speculating, intervening, observing reporting, writing and presenting [14].

In general, approaches towards AR as a cyclical, systematic and dynamic process mostly applied in social science alongside with applied linguistics and educational field are so different that teacher researchers need to get acquainted with educational AR theoretical background appropriately. It goes without saying, that teacher researchers' efficient and systematic integration of AR into practice will lead them to creating their own innovative AR design. In this sense, Kemmis highlights the importance of getting well informed about AR theory for practitioners, first, to become the so-called 'theorists' and then researchers in the process of action research as self-transformation and meta practice or practice-changing-practice approach. 
What sequential stages of AR process should teachers undergo when conducting CAR?

The consecutive stages of AR process in teachers' research practice are given in Table 1 which may help novice teachers to gain a better understanding about CAR and creating their own research projects in future.

T a b l e 1

Sequential stages of CAR process in teaching practice

\begin{tabular}{|c|c|c|}
\hline & $\begin{array}{c}\text { Classroom action research } \\
\text { procedures }\end{array}$ & Additional information for teacher researchers \\
\hline 1 & Literature review & $\begin{array}{l}\text { Getting acquainted with different types of AR theoretically: class- } \\
\text { room action research, critical participatory action research, technical } \\
\text { action research, practical action research [15]. Choosing appropriate } \\
\text { one (individual, pair, and group) for research project }\end{array}$ \\
\hline 2 & $\begin{array}{l}\text { Keeping a reflective journal/ } \\
\text { diary }\end{array}$ & $\begin{array}{l}\text { It is really important for teacher researchers to start writing their } \\
\text { thoughts about AR practice in their reflective journals which later } \\
\text { contribute to developing their meta-cognitive, creative, research and } \\
\text { critical thinking skills }\end{array}$ \\
\hline 3 & $\begin{array}{l}\text { Teacher researcher's self- } \\
\text { understanding about empiri- } \\
\text { cal investigation }\end{array}$ & $\begin{array}{l}\text { eacher researcher's familiarizing with quantitative and qualitative } \\
\text { hethods of investigation theoretically in order to collect, analyze and } \\
\text { valuate data in practice competently }\end{array}$ \\
\hline 4 & $\begin{array}{l}\text { Choosing a class for re- } \\
\text { search. Selecting an issue. } \\
\text { Formulating a specific re- } \\
\text { search question related to the } \\
\text { problem }\end{array}$ & $\begin{array}{l}\text { Carrying out pre-diagnostic quantitative and qualitative inquiry: ob- } \\
\text { servation, interview, questionnaire, socio metric survey, case study, } \\
\text { and focus group discussion. Problem diagnosis. Data collected from } \\
\text { several sources (interview, and socio metric survey and focus group } \\
\text { discussion) is known as 'triangulation' which is of great importance } \\
\text { to make the inquiry reliable, valid and objective }\end{array}$ \\
\hline 5 & $\begin{array}{l}\text { Designing an action research } \\
\text { project. Creating AR sched- } \\
\text { ule }\end{array}$ & $\begin{array}{l}\text { procedures. Constructing curriculum } \\
\text { re focused on learning based problem }\end{array}$ \\
\hline 6 & Ethical considerations & $\begin{array}{l}\text { confidentiality, research's transparen- } \\
\text { uld be taken into consideration. }\end{array}$ \\
\hline 7 & $\begin{array}{l}\text { Conducting a theory and } \\
\text { practice based action re- } \\
\text { search }\end{array}$ & $\begin{array}{l}\text { Undergoing through AR stages: planning, action, observing, reflect- } \\
\text { ing. Focusing on learners' needs, voices, learning styles, and strate- } \\
\text { gies when choosing and implementing efficient teaching strategies, } \\
\text { and techniques related to the problem }\end{array}$ \\
\hline 8 & $\begin{array}{l}\text { Data collection, data analy- } \\
\text { sis. Critical inquiry }\end{array}$ & $\begin{array}{l}\text { ess through data collection and analysis. } \\
\text { iagnostic results. Representing findings and }\end{array}$ \\
\hline 9 & $\begin{array}{l}\text { itical reflection and evalu- } \\
\text { on. Developing an action }\end{array}$ & $\begin{array}{l}\text { Reconstructing curriculum aims and principles. Constructing a new } \\
\text { theory into classroom practice }\end{array}$ \\
\hline 10 & Next action research cycle. & Conducting next AR cycle if the problem has not been resolved yet \\
\hline 11 & $\begin{array}{l}\text { Creating AR portfolio. } \\
\text { Disseminating findings and } \\
\text { results }\end{array}$ & $\begin{array}{l}\text { Sharing results with colleagues through webinars, seminars, and } \\
\text { trainings and coaching. Publishing articles and brochures. Demon- } \\
\text { strating AR project and poster presentations to a wider audience }\end{array}$ \\
\hline
\end{tabular}

To get a clearer picture about AR procedure Richard \& Farrell suggest to take the following steps which involve first, selecting an issue (focus on specific issue and identify concrete research questions related to the problem), second, teacher's theory based and practical actions and data collected through observational (notes, diaries, audio and video recordings, transcripts, diagrams) and non-observational (interviews, discussions, questionnaires, surveys, documents, life histories) methods [16], third, developing AR plan and observing its effects in terms of problem solving and making changes in teaching strategies, techniques, teaching materials, and assessment, and finally disseminating results with the help of oral, written, poster and vid- 
eo presentations, workshops, and internet forums. Together with this, it is important to publish articles which can be helpful for other teacher researchers to compare and analyze findings with their own research, to implement new strategies in their further investigation. One of the most significant challenges in AR process is how to select an issue, formulate a specific research question, gather data and represent findings related to the problem statement. Richard \& Farrell address this challenge demonstrating AR sequential steps presented in Table 2. It includes several examples of possible learning based problems, research questions, data collection and representing findings.

Table 2

Richard \& Farrell's steps in conducting action research: problem statement, research questions, data collection and representing findings

\begin{tabular}{|c|c|c|c|}
\hline $\begin{array}{l}\text { Problem } \\
\text { statement }\end{array}$ & $\begin{array}{l}\text { Specific research } \\
\text { questions }\end{array}$ & $\begin{array}{l}\text { Action research process } \\
\text { How to collect data to resolve the issue }\end{array}$ & Representing findings \\
\hline 1 & 2 & 3 & 4 \\
\hline $\begin{array}{l}\text { Some students } \\
\text { in my class have } \\
\text { difficulties } \\
\text { communicating } \\
\text { with one anoth- } \\
\text { er. They do not } \\
\text { participate in } \\
\text { speaking activi- } \\
\text { ties. }\end{array}$ & $\begin{array}{l}\text { What are the } \\
\text { most effective } \\
\text { speaking strate- } \\
\text { gies and tech- } \\
\text { niques to use for } \\
\text { improving stu- } \\
\text { dents' speaking } \\
\text { skills? }\end{array}$ & $\begin{array}{l}\text { To implement different interactive speak- } \\
\text { ing activities, types of interaction, to au- } \\
\text { diotape and videotape lessons, take inter- } \\
\text { views, questionnaires and conduct focus } \\
\text { group discussions in order to identify stu- } \\
\text { dents' voices and needs. To write regular } \\
\text { entries in a reflective journal with the aim } \\
\text { of revealing students' strengths and } \\
\text { weaknesses related to the problem. }\end{array}$ & $\begin{array}{l}\text { Pair work activities } \\
\text { turned out to be more } \\
\text { beneficial rather than } \\
\text { group work problem } \\
\text { solving activities. It } \\
\text { motivated every stu- } \\
\text { dent to discuss a par- } \\
\text { ticular topic with his } \\
\text { or her partner more } \\
\text { confidently. }\end{array}$ \\
\hline $\begin{array}{l}\text { Despite my im- } \\
\text { plementing error } \\
\text { correction strat- } \\
\text { egies, my stu- } \\
\text { dents keep on } \\
\text { making mistakes } \\
\text { in their writing } \\
\text { activities. }\end{array}$ & $\begin{array}{l}\text { What error cor- } \\
\text { rection strate- } \\
\text { gies should I } \\
\text { implement to } \\
\text { enhance my stu- } \\
\text { dents' accuracy } \\
\text { in their writing? }\end{array}$ & $\begin{array}{l}\text { To use different types of error correction } \\
\text { strategies in students writing activities and } \\
\text { identify which of them are more effective } \\
\text { for students' productive writing. To audi- } \\
\text { otape and videotape lessons, case study } \\
\text { students, to give students constructive } \\
\text { feedback after careful observation during } \\
\text { the lessons, to take interviews and con- } \\
\text { duct discussions with the purpose of help- } \\
\text { ing students to overcome barriers. }\end{array}$ & $\begin{array}{l}\text { Teacher indicated stu- } \\
\text { dents' errors and cor- } \\
\text { rected their grammar } \\
\text { mistakes all the time } \\
\text { whereas students ana- } \\
\text { lyzed only their cor- } \\
\text { rected mistakes; they } \\
\text { did not write their es- } \\
\text { says a second time in } \\
\text { order to give a detailed } \\
\text { error correction analy- } \\
\text { sis to their corrected } \\
\text { essays. }\end{array}$ \\
\hline $\begin{array}{l}\text { My students do } \\
\text { not interact with } \\
\text { one another ac- } \\
\text { tively when they } \\
\text { work in groups. } \\
\text { It seems to me } \\
\text { that I should } \\
\text { change the way } \\
\text { of my teaching } \\
\text { strategies. }\end{array}$ & $\begin{array}{l}\text { What group } \\
\text { work procedures } \\
\text { are the most } \\
\text { productive for } \\
\text { my students to } \\
\text { interact and col- } \\
\text { laborate with } \\
\text { one another suc- } \\
\text { cessfully? }\end{array}$ & $\begin{array}{l}\text { To conduct socio metric survey to pose the } \\
\text { problem. To identify the problem in group } \\
\text { work through interviews, questionnaires, } \\
\text { surveys and discussions. Teacher's self- } \\
\text { monitoring and self-reflection about his or } \\
\text { her teaching group-work strategies. To car- } \\
\text { ry out various group work activities in } \\
\text { class taking students' voices, group size, } \\
\text { role distribution, learner needs, characteris- } \\
\text { tics and styles into consideration. To col- } \\
\text { lect documents related to students' work, } \\
\text { analyze and evaluate them properly. }\end{array}$ & $\begin{array}{l}\text { Different roles were } \\
\text { distributed to students } \\
\text { for their open discus- } \\
\text { sion on various topics. } \\
\text { Teacher's group work } \\
\text { strategies were effec- } \\
\text { tive enough to stimu- } \\
\text { late students to interact } \\
\text { with one another co- } \\
\text { operatively. }\end{array}$ \\
\hline $\begin{array}{l}\text { I would like to } \\
\text { know whether } \\
\text { my oral error } \\
\text { correction strat- } \\
\text { egies are effec- } \\
\text { tive or not. }\end{array}$ & $\begin{array}{l}\text { What are the } \\
\text { most successful } \\
\text { oral error cor- } \\
\text { rection strate- } \\
\text { gies for my stu- } \\
\text { dents' com- }\end{array}$ & $\begin{array}{l}\text { To use different types of oral error correc- } \\
\text { tion strategies and identify which of them } \\
\text { are more effective for students' communi- } \\
\text { cating more fluently. To audiotape and } \\
\text { videotape lessons, to give students con- } \\
\text { structive feedback after careful observa- }\end{array}$ & $\begin{array}{l}\text { Mostly the teacher } \\
\text { corrected students' } \\
\text { mistakes by interrupt- } \\
\text { ing them. However, } \\
\text { some students correct- } \\
\text { ed their mistakes }\end{array}$ \\
\hline
\end{tabular}




\begin{tabular}{|l|l|l|l|}
\hline \multicolumn{1}{|c|}{2} & \multicolumn{1}{|c|}{3} & \multicolumn{1}{c|}{4} \\
\hline & $\begin{array}{l}\text { municating } \\
\text { more fluently? }\end{array}$ & $\begin{array}{l}\text { tion, to take interviews and conduct dis- } \\
\text { cussions with the purpose of helping stu- } \\
\text { dents to feel more confidently when } \\
\text { communicating with one another in class. }\end{array}$ & $\begin{array}{l}\text { theachers interruption. } \\
\text { teaches }\end{array}$ \\
\hline
\end{tabular}

\section{Issues in Kazakhstan Education and Necessity to Transform Core Curriculum through Action Research}

\section{What key issues do Kazakhstani teachers and students face in the educational field?}

Primary challenges revealed by OECD Educational Policy Outlook [17] as follows: school's insufficient resources, problems with the status of teaching and school leadership, teachers' lower level of autonomy in terms of teachers' obedience to subject content. Students' challenges as follows: low level of reading performance in PISA, decline in learning outcomes due to teachers' obedience to entirely theoretical school curriculum, which lead to students' effective remembering and keeping information in mind but puts big challenges in reflecting on and evaluating reading texts, applying acquired knowledge to everyday life, in other words developing functional literacy [18]. The key challenge arisen in front of Kazakhstani teachers is how to develop students' higher order thinking skills.

How about university undergraduate and academic staff challenges? For example, a survey carried out with 300 students in three major technical universities such as K. Satbayev Kazakh National Research Technical University, (KazNRTY), Kazakh- British Technical University, (KBTU), International Information Technology University (IITU) [19] revealed academic issues such as difficulties in grammar, pronunciation vocabulary, reading, and speech, $56.7 \%$ of students' dissatisfaction with their school education, $60 \%$ of respondents' private lesson attendance to enter the university and undergraduates' lack of certainty to express their points of view in English freely. Correspondingly, academic staff related challenges as follows: some EFL teachers' lower training quality, discrepancy of textbooks in the didactic, methodological and cultural contexts, less collaboration among EFL faculty, overloaded students in the classrooms, a shortage of instructional and technical resources for effective teaching, problems with error correction, time management, teaching foreign students, low payment, and inappropriate schedules. Consequently, from the authors' perspectives the above mentioned challenges should be resolved in the following way: introduction of courses for beginners, increasing the number of credit hours, providing with multimedia training programs, teachers' conducting peer observations, teaching trainings, collaboration with foreign experts, involving university students in out-of-class activities, speaking clubs, webinars, organizing competitions, Olympiads and debates, raising the responsibility of school teachers because school leavers' knowledge does not correspond with standardized educational norms to continue education for beginners at university level. It is true to say that nowadays school education levels are different in Kazakhstan, for instance, Nazarbayev Intellectual Schools (NIS) and Kazakh-Turkish lyceums where students' knowledge level is rather higher than mainstream schools due to their rigorous academic selection. The next raised question is how to improve comprehensive school students' cognitive skills in parallel with language skills.

What are the possible solutions to resolve issues in Kazakhstan teacher education?

To tackle the problem and meet international education standard radical changes occurred in Kazakhstan: establishment of teaching training by Centers of Excellence, introduction of 12 year education, teaching Biology, Chemistry, Physics and ICT in English and upgrading teachers' qualification courses. Kazakhstan school curriculum has been transformed entirely focused on competence based approach which contributes to developing students' educational competences and superior job performance in future. Nowadays action research and lesson study (LS) approaches are being introduced into Kazakhstani retraining teacher qualification courses however they are not integrated into school teaching practice systematically as one of the requirements. To address the issues, major steps should be taken to overcome educational barriers, namely to introduce continuous AR and LS courses into teacher educational programme for in-service training as one of the requirements of sustainability of effective professional development. Furthermore, it is necessary to include AR as 'a theory-driven and practice based discipline' in pre-service education to help graduates become competent teacher researchers in their future teaching career. What is the point of introducing AR into universities as a theory-driven and practice based discipline? As it was argued above, a lack of in-service teachers' theoretical and practical AR knowledge is the main challenge in teachers' research progression. It is important to prepare undergraduates at universities to gain a deeper understanding about AR characteris- 
tics, principles and concepts, stages of action research methodology so as to implement them efficiently in their future teaching practice. The next point to bear in mind is to give opportunity for postgraduates to conduct empirical and scientific AR investigations on the basis of 'case study methodology', as it was argued by McKernan, in order to create innovative AR models through critical reflective practice.

\section{Discussion: Possible Solutions to Resolve Action Research Challenges}

In general, teachers' AR experience from the UK, Singapore, the state of New South Wales in Australia, Thailand, Iran and Philippine demonstrate the truth that theory is one side of the coin and practice is another one which requires taking personal, social, cultural, and professional aspects into consideration namely, hard work, research literacy, motivation, desire to investigate, enthusiasm, readiness to learn from mistakes, extra time, mutual understanding, critical reflection and financial support. It is natural that weaknesses revealed from teachers' AR practice constitute a large portion rather than strengths because in educational AR process firstly, teacher researchers investigate challenges mostly from the perspective of the whole classroom environment which is rather difficult to concentrate as a whole. Secondly, it is not always possible for team members to meet together and observe lessons in collaboration due to different reasons which in its turn complicates the whole procedure. And thirdly, AR is a longitudinal, time-consuming process demanding repeatability of its cycles from practitioners if there is the need to take further actions and do the next research. Kazakhstani teacher researchers regard action research as a useful inquiry-based approach which undoubtedly proves its effectiveness in case it is implemented systematically in collaborative educational institutions to enhance CPD.

Why is it necessary to introduce AR into school teaching practice as one of the requirements? Because it is an efficient approach:

- to enhance teacher education, identify and resolve learning based and teaching practical problems which result in developing teachers' own innovative AR projects in the light of collaboration, cooperation and collegiality, sharing findings with academic staff, thus, becoming competent experts at exploring teaching classroom problems as it was highlighted by Richard \& Farrell.

- to change teaching practice radically, in other words, to transform a research practice into living theories or personal theories which serve as a basis for developing new practices and teacher researchers' teaching strategy transformation [20].

- to transform and update curriculum through develop educational inquiry and professional code of ethics [21].

- to develop high quality education and sustainability in CPD [22].

- to design a modernized model of curriculum aims and principles of learner-centred education', 'independent/autonomous learning', 'self-directed learning', 'enquiry/discovery learning', 'collaborative learning', 'active learning' and 'learning with understanding', as it was argued by Elliott.

\section{Conclusion}

Focused on both theory and practice, educational action research is a powerful vehicle as a problem posing and problem solving approach in continuous teacher education. It is an ongoing, cyclical, and critical inquiry which provides a basis for successful teaching and learning. At the same time, it involves different challenges in terms of personal, interpersonal, professional and cultural aspects. AR issues revealed in the UK, Philippine, Thailand, Iran, Singapore and New South Wales and challenges in Kazakhstan education can be resolved in case innovative AR process is actively introduced into retraining qualification courses and developed in schools continuously. In addition, it is necessary to include 'a theory and practice based research' discipline into universities which afterwards may shed the light on successful research progress. Teachers' insufficient knowledge about action research methodology is one of the main reasons for attracting academics, experts to schools which can provide a basis for sustainable continuous professional development. Those who undergo through these procedures may overcome faced issues, transform their teaching styles altogether, enhance students' learning outcomes, remodel teaching strategies, techniques, and create new theories into classroom practice which may lead to productive curriculum transformation. For schools, colleges and universities AR process is undoubtedly efficient as it is focused on both teachers' teaching and students' learning challenges which can be resolved by teacher researchers' collaborative interaction in the light of critical reflection. 


\section{References}

1 Richards, J.C., \& Farrell, T.S.C. (2005). Professional development for language teachers: Strategies for teacher learning. Ernst Klett Sprachen.

2 Elliott, J. (2015). Educational action research as the quest for virtue in teaching. Educational Action Research, 23(1), 4-21.

3 Kemmis, S. (2009). Action research as a practice-based practice. Educational Action Research, 17(3), 463-474.

4 Stenhouse, L. (1975). An Introduction to Curriculum Research and Development. London: Heinemann.

5 Hughes, G.J. (2001). Aristotle on Ethics. London \& New York: Routledge.

6 Carr, W. (2004). 'Philosophy and Education', Journal of Philosophy of Education, Vol. 38, No. 1, 3-16.

7 Pearson, J. (2017). Who is afraid of Action Research: the risky practice of immanent critique. Language Scholar Journal, 1(1), 2-21.

8 Ellis, N., \& Loughland, T. (2016). The challenges of practitioner research: A comparative study of Singapore and NSW. Australian Journal of Teacher Education, 41(2), 8.

9 Kunlasomboon, N., Wongwanich, S., \& Suwanmonkha, S. (2015). Research and development of classroom action research process to enhance school learning. Procedia-Social and Behavioral Sciences, 171, 1315-1324.

10 Dehghan, F, Sahragard, R. (2015). Iranian EFL Teachers' Views on Action Research and Its Application in Their Classrooms: A Case Study. Journal of Teacher Education and Educators, 4 (1), 39-52.

11 Ulla, M.B. (2018). Benefits and challenges of doing research: Experiences from Philippine public school teachers. Issues in Educational Research, 28(3), 797-810.

12 Kemmis, S., \& McTaggart, R. (1998). The nature of action research. the action research planner. Deakin University (Australia).

13 McKernan, J. (2013). Curriculum action research: A handbook of methods and resources for the reflective practitioner. Routledge.

14 Burns, A. (2005). Action research: An evolving paradigm? Language teaching, 38(2), 57-74.

15 Kemmis, S., McTaggart, R., \& Nixon, R. (2013). The action research planner: Doing critical participatory action research. Springer Science \& Business Media.

16 Burns, A. (1999). Collaborative action research for English language teachers. Cambridge: Cambridge University Press

17 EDUCATION POLICY OUTLOOK: KAZAKHSTAN (C OECD 2018. Retrieved from: http://iac.kz/en/events/oecd-releasedcountry-profile-education-policy-outlook-kazakhstan

18 Handbook for teachers. Reviews of National Policies for Education: Secondary Education in Kazakhstan, OECD (2014). Retrieved from: https://b-ok.asia/book/3342988/d1c280?regionChanged

19 Abdygapparova, S., \& Smirnova. L. (2018). Teacher and teaching challenges in EFL higher education in Kazakhstan, Asia Pacific Institute of Advanced Research (APIAR), 19-25.

20 McNiff, Jean and Whitehead, Jack (2011). All you need to know about action research. (2nd ed.). SAGE Publications.

21 McKernan, J. (2007). Curriculum and imagination: Process theory, pedagogy and action research. Routledge.

22 Edwards, E., \& Burns, A. (2015). Language teacher action research: Achieving sustainability. Elt Journal, 70(1), 6-15.

\section{Г.А. Ризаходжаева, Н.С. Ибадуллаева}

\section{Іс-әрекеттегі зерттеу әдісі - білім берудегі қайта құрудың куатты құралы}

Білім беру саласындағы маңызды мәселелердің бірі - мұғалімдердің мектеп іс-тәжірибесінде теория мен практикаға негізделген іс-әрекеттегі зерттеу «action research» әдісі негізінде оқыту мен зерттеуді үйлестіре алмауы. Бұл мәселені шешу үшін мақалада теория және практиканы ұштастырған ісәрекеттегі зерттеу әдісінің егжей-тегжейлі зерттелуі, осы әдісті зерттеу барысында алты елде туындаған сұрақтар және Қазақстанның білім беру мәселелері салыстыру мен қарама-қайшылықтар, ұқсастықтар мен айырмашылықтар сияқты сыни рефлексия тұрғысынан қарастырылған. Әртүрлі елдердің іс-әрекеттегі зерттеу тәсілдерін зерделеу кезінде анықталған ұқсас мәселелер: мұғалімдердің жеке, ішкі, әлеуметтік, кәсіби және мәдени мәселелері, іс-әрекеттегі зерттеу теориясы мен практикасы туралы жеткіліксіз білім, нәтижелерді құжаттау және ұсыну мәселелері. Осы күрделі мәселелерді шешу мақсатында мақалада іс-әрекеттегі зерттеу әдісінің тізбектелген принциптері қарастырылған, ісәрекеттегі зерттеу әдісін нәтижелі жүзеге асыру мақсатында мамандарды іс-тәжірибе алмасуға шақыру, жүйелі түрде зерттеу жұмыстарын жүргізудің негізгі талаптарының бірі ретінде мұғалімдердің біліктілігін арттыру курстарына «іс-әрекеттегі зерттеу» курсын енгізу қажеттілігі айқындалған. «Теория мен практикаға негізделген іс-әрекеттегі зерттеу» пәнін жоғары оқу орындарына енгізудегі басты мақсат - студенттер мен магистранттарды «іс-әрекеттегі зерттеу әдісі бойынша әдістемелік нұсқаулық» жасауға ынталандыру. Жалпы алғанда, іс-әрекеттегі зерттеу әдісі оқу жоспарының мақсаттары мен қағидаларын, оқытудың стратегиялары мен әдістерін қайта құрудың түпкілікті құралы болуына күмән жоқ. Оқыту іс-тәжірибесін зерттеу барысында туындайтын кедергілер мұғалімдердің сындарлы және бірлескен сыни пікірлерімен бірлесіп шешілген жағдайда оң нәтиже беруі тиіс. 
Кілm сөздер: іс-әрекеттегі зерттеу, оқытушы зерттеушілер, мәселелер, теория мен практика, педагогикалық практика, оку жоспары, процесс.

\section{Г.А. Ризаходжаева, Н.С. Ибадуллаева}

\section{Исследование в действии - путь к трансформации в сфере образования}

Одной из наиболее значительных проблем в области образования является неспособность учителей сочетать преподавание и исследование в контексте процесса «исследование в действии» («action research»), основанного на теории и практике. Для решения этой проблемы в статье рассмотрены подробные теоретические и практические исследования, проблемы, выявленные в шести странах на основе подхода «исследование в действии», также вопросы казахстанского образования, которые раскрываются в свете критических размышлений: сравнение и противопоставление, сходства и различия. Схожие проблемы, выявленные при изучении данного подхода в разных странах, заключаются в следующих аспектах: личные, внутриличностные, социальные, профессиональные и культурные проблемы учителей, недостаточные знания теории и практики, проблемы с документированием и представлением результатов на основе подхода «action research». Для решения этих сложных вопросов авторами предложены разработанные принципы последовательных действий «action research», внедрение цикла «action research» в курсы переподготовки учителей, привлечение экспертов к сотрудничеству с учителями в успешной реализации практических исследований. Кроме того, необходимо внедрение дисциплины «Теоретическое и практическое исследование в действии» в высшее учебное образование, с целью побуждения студентов, магистрантов разработать руководство по данному подходу. В целом, подход «исследование в действии» станет основным инструментом для воссоздания целей и принципов учебной программы, перестройки стратегий и методов обучения и преобразования обновленной основной учебной программы в случае, если многочисленные барьеры будут устранены в рамках конструктивного и совместного критического анализа учителей.

Ключевые слова: исследование в действии, учитель-исследователь, проблемы, теория и практика, педагогическая практика, учебный план, процесс. 